\title{
Reaction of potential guava rootstocks to Meloidogyne enterolobii
}

\author{
Fernando Marcelo Chiamolera ${ }^{1 *}$, Antonio Baldo Geraldo Martins², Pedro Luiz Martins Soares ${ }^{3}$, \\ Tatiana Pagan Loeiro da Cunha-Chiamolera ${ }^{4}$ \\ $10.1590 / 0034-737 X 201865030010$
}

\begin{abstract}
Root-knot nematode Meloidogyne enterolobii is the main phytosanitary problem of guava cultivation in Brazil. Among the strategies to manage the problem, the best prospects are in identifying or developing cultivars or rootstocks that are resistant to this nematode. To identify plants with potential as rootstocks for guava, the reaction of araçá (wild guava) to $M$. enterolobii was assessed in a greenhouse experiment. Seven araçá species were evaluated (Eugenia stipitata, Psidium acutangulum, P. cattleyanum 'yellow', $P$. friedrichsthalianum, $P$. guajava var. minor, $P$. guineense, and Psidium sp.). The plants were inoculated with a suspension of 3,000 eggs of $M$. enterolobii, using eggplant as control treatment. The parameters fresh root mass, number of eggs and second stage juveniles (J2) per root system, the reproduction factor $(\mathrm{RF}=\mathrm{Pf} / \mathrm{Pi})$, and araçá reaction were determined during the experiment. $\mathrm{RF}$ of the araçá species $E$. stipitata, P. cattleyanum 'yellow', and P. friedrichsthalianum was less than one (RP<1), therefore resistant to $M$. enterolobii. The araçá trees had good root system development and the susceptible plants showed many root galls, high number of eggs and J2, and Fusarium solani and Rhizoctonia solani root rot. The araçá species, P. cattleyanum 'yellow', P. friedrichsthalianum, and E. stipitata are resistant to M. enterolobii and can be tested as potential guava rootstocks.
\end{abstract}

Keywords: Psidium guajava; araçá species; root-knot nematode; genetic resistance.

\section{RESUMO}

\section{Reação de possíveis porta-enxertos de goiabeira a Meloidogyne enterolobii}

O nematoide das galhas, Meloidogyne enterolobii, é o principal problema fitossanitário para o cultivo da goiabeira. Entre as estratégias para o manejo deste nematoide, as melhores perspectivas estão na identificação ou no desenvolvimento de cultivares ou porta-enxertos resistentes. Buscando elucidar quais plantas poderão ser testadas como portaenxertos de goiabeira, um experimento foi conduzido em casa de vegetação com o objetivo de avaliar a reação de araçazeiros frente a M. enterolobii. Sete espécies de araçazeiros foram avaliadas (Eugenia stipitata, Psidium acutangulum, P. cattleyanum 'amarelo', P. friedrichsthalianum, P. guajava var. minor, P. guineense e Psidium sp.), as quais foram inoculadas com uma suspensão de 3.000 ovos de $M$. enterolobii, sendo utilizadas plantas de berinjela como tratamento controle. Durante as avaliações, foram determinados a massa fresca de raízes, o número de ovos e juvenis de segundo estádio (J2) por sistema radicular, o fator de reprodução [FR = Pf/Pi] e a reação dos araçazeiros. Os araçazeiros, $E$. stipitata, $P$. cattleyanum 'amarelo' e $P$. friedrichsthalianum tiveram fator de reprodução menor que um (FR $<1)$, sendo, portanto, resistentes a $M$. enterolobii. Nesses araçazeiros houve bom desenvolvimento do sistema radicular e nas plantas suscetíveis (FR>1) foram observadas muitas galhas, elevado número de ovos e J2 e necroses nas raízes, com a presença de Fusarium solani e Rhizoctonia solani. Os araçazeiros, P. cattleyanum 'amarelo', P. friedrichsthalianum e E. stipitata são resistentes ao M. enterolobii e podem ser testados como possíveis porta-enxertos de goiabeira.

Palavras-chave: Psidium guajava; araçazeiros; nematoide das galhas; resistência genética.

Submitted on March 23rd, 2017 and accepted on April 09th, 2018.

1Faculdades do Centro do Paraná, Pitanga, Paraná, Brazil. chiamolera@ hotmail.com

2Universidade Estadual Paulista, Faculdade de Ciências Agrárias e Veterinárias, Departamento de Produção Vegetal, Jaboticabal, São Paulo, Brazil. baldo@fcav.unesp.br 3Universidade Estadual Paulista, Faculdade de Ciências Agrárias e Veterinárias, Departamento de Fitossanidade, Jaboticabal, São Paulo, Brazil. pedrolms@ @cav.unesp.br 4Faculdade Campo Real, Guarapuava, Paraná, Brasil. tatiana.pagan@hotmail.com

*Corresponding author: chiamolera@ hotmail.com 


\section{INTRODUCTION}

In the late 1980s, severe damage to guava (Psidium guajava) caused by root-knot nematodes was diagnosed and attributed to Meloidogyne incognita [(Kofoid \& White) Chitwood] (Moura \& Moura, 1989). Later, these damages were related to Meloidogyne enterolobii (Yang \& Eisenback), and, in Brazil, the first recorded parasitism occurred in irrigated orchards of Bahia and Pernambuco (Carneiro et al., 2001).

M. enterolobii is the main limiting factor for guava cultivation and the typical symptoms of the disease are tanning, yellowing, and fall of leaves, leading to plant death (Carneiro et al., 2001). The infected roots present numerous galls, generalized necrosis, and few radicels, which aggravate the symptoms of nutritional deficiency (Almeida et al., 2011). In addition, infection by $M$. enterolobii in guava is generally associated with soil fungi (Gomes et al., 2013), which interact synergistically resulting in greater damage to crops, as reported for common bean (Phaseolus vulgaris) and passion fruit (Passiflora edulis f.flavicarpa) (Fischer et al., 2010; Al-Hazmi \& Al-Nadary, 2015).

An estimate of direct damages in guava orchards associated with $M$. enterolobii infection was carried out in the states of Bahia, Ceará, Pernambuco, Rio Grande do Norte, and Rio de Janeiro and, reported a loss of more than US \$ 60 million, without accounting for impacts on other sectors of the crop production chain. In addition to the decapitalization of small-farmers, as guava orchards are usually cultivated by family farmers, rural labor unemployment is added and negatively affects the regional economy (Pereira et al., 2009).

After its identification and the damage caused to guava, M. enterolobii gained worldwide importance, and its polyphagia was detected in many plants of economic interest, such as fruit (Carica papaya and Malpighia emarginata) and vegetables (Citrullus lanatus, Lactuca sativa, Solanum lycopersicum, Solanum melongena, among others) (Rosa et al., 2015; Silva et al., 2016).

Among the strategies for managing $M$. enterolobii in guava, the use of organic compost (avian litter and cattle manure) applied to the crown projection is more feasible in moderately infested orchards (Gomes et al., 2010). The use of antagonistic plants and/or unfavorable hosts is also an alternative for managing nematodes, since they reduce the populations and are used as green manures (Avena spp., Urochloa spp., Crotalaria spp., Mucuna spp., Pennisetum glaucum, and Raphanus sativus var. oleiferus) or for grain production (Arachis hypogaea) (Cunha et al., 2015; Rosa et al., 2015; Silva \& Santos, 2017).

However, the best prospects for the management of $M$. enterolobii in guava orchards are in the identification or development of resistant cultivars or rootstocks. Some studies evaluated the reaction of araçá and guava trees to M. enterolobii and found sources of resistance (Almeida et al., 2009; Freitas et al., 2014; Biazatti et al., 2016). However, most of the evaluated species are susceptible to M. enterolobii and results diverge for some araçá species as in Psidium cattleyanum and P. friedrichsthalianum (Almeida et al., 2009; Freitas et al., 2014).

Thus, the objective of this study was to evaluate the reaction of araçá species to $M$. enterolobii and to diagnose the possible presence of fungi in the roots, seeking to identify which genotypes could be tested as rootstock for guava.

\section{MATERIAL AND METHODS}

The experiment was conducted in a greenhouse in the municipality of Jaboticabal, São Paulo State, Brazil (2114'33"'S; 48¹7'02'W; 563 m altitude), from August 21, 2013 to July 10, 2014.

A completely randomized design was used, with eight treatments (araçá trees), one control (eggplant), and ten replications. The following wild araçá species were evaluated: yellow-araçá (Psidium cattleyanum), araçázeiroboi (Eugenia stipitata), araçázeiro-do-campo ( $P$. guineense), araçázeiro-mirim (Psidium sp.), araçázeiro-pera (P. acutangulum), goiabeira-mirim (P. guajava var. minor), and two genotypes of Costa Rican guava ( $P$. friedrichsthalianum).

Seeds were planted in perforated polyethylene trays $(43 \times 28 \times 11 \mathrm{~cm})$ filled with expanded vermiculite of medium texture, and kept under a $50 \%$ shade screen. The seedlings, approximately $5 \mathrm{~cm}$ in height, were transplanted into $3.8 \mathrm{~L}$ polyethylene vessels filled with a mixture (1:2) of soil and sand, which was autoclaved at $120{ }^{\circ} \mathrm{C}$ for $2 \mathrm{~h}$. After transplanting, the seedlings were kept in the greenhouse free of nematodes for approximately four months to achieve better growth rate and development, mainly the root system, until inoculation.

The inoculum was obtained from roots of 'Paluma' guava, of a commercial plantation of approximately 12 years, in Vista Alegre do Alto, São Paulo State. A subpopulation of $M$. enterolobii was identified based on the morphological characters of the perineal pattern (Taylor \& Netscher, 1974), the labial region morphology in males (Eisenback \& Hirschimann, 1981), and the esterase isoenzymatic phenotype (Esbenshade \& Triantaphyllou, 1990).

We prepared a $M$. enterolobii egg suspension from infected roots using $0.5 \%$ aqueous solution of sodium hypochlorite (Hussey \& Barker, 1973), on January 8, 2014. Then, the araçá seedlings were inoculated with a suspension of $10 \mathrm{~mL}$, containing 3,000 eggs. The suspension was pipetted into six holes in the substrate around the collar of the plants. To assess the viability of 
the inoculum, 'Comprida Roxa' eggplant plants were used as susceptibility pattern (control treatment).

The plants were irrigated according to need and fertilized according to production guidelines for guava seedlings (Franco \& Prado, 2006). About six months after inoculation (183 days), the root system was removed, washed in running water, the excess water removed with paper towel, and the fresh mass determined. The roots were processed according to Hussey \& Barker (1973) and, after extractions, the number of eggs and $\mathrm{J} 2$ of $M$. enterolobii in the root systems was estimated using a Peters' counting slide under light microscope. Araçá and eggplant root samples were sent to the Phytopathology Laboratory of the School of Agricultural and Veterinary Studies of the Universidade Estadual Paulista (FCAV/ UNESP) to determine the presence of fungi. The identification, was performed through the morphological characteristics of fungi growth by direct observation in optical microscope.

The reproduction factor $(\mathrm{RF})$ was determined by the equation $[\mathrm{RF}=\mathrm{Pf} / \mathrm{Pi}]$ where: $\mathrm{Pf}=$ final population and $\mathrm{Pi}=$ initial population ( $\mathrm{Pi}=3,000$ eggs). The araçá plants with $\mathrm{RF}<1$ were considered resistant and those with $\mathrm{RF}>1$ were considered susceptible (Oostenbrink, 1966). For the purpose of analysis, the number of eggs and $\mathrm{J} 2$ were transformed into $\log (x+5)$, submitted to analysis of variance by the $\mathrm{F}$ test, and the means were compared by the Tukey's test at $1 \%$ of probability $(\mathrm{p}<0.01)$.

\section{RESULTS AND DISCUSSION}

$M$. enterolobii did not multiply in the species yellowaraçá (Psidium cattleyanum) and Costa Rican guava ( $P$. friedrichsthalianum), which were classified as resistant, with RF < 1 (Table 1), corroborating results in the literature (Freitas et al., 2014; Biazatti et al., 2016). Freitas et al. (2014) observed that the roots of yellow-araçá (Psidium cattleyanum) and Costa Rican guava ( $P$. friedrichsthalianum) were infected by $M$. enterolobii and the $\mathrm{J} 2$ induced formation of feeding sites, but, about 30 days after inoculation, the giant cells deteriorated and most of the specimens of $M$. enterolobii did not reach maturity.

The resistance of yellow-araçá (Psidium cattleyanum) and Costa Rican guava (P. friedrichsthalianum) may result from a mechanism called post-infection or delayed resistance, in which the nematodes are able to penetrate the roots but do not develop (Freitas et al., 2014). In plants possessing post-infection resistance, cell death around the area of infection occurs and prevents the formation and development of the feeding site, giving resistance to the plants. This type of resistance mechanism to gall nematodes was also reported for genotypes of cowpea
(Vigna unguiculata) and rice (Oryza glaberrima) (Das et al., 2008; Cabasan et al., 2014).

E. stipitata allowed a little multiplication of $M$. enterolobii, however, it was also classified as resistant $(\mathrm{RF}<1)$ (Table 1). This result corroborates with the results of Almeida et al. (2009) who evaluated roots of the plants and obtained a reproduction factor of 0.09 after five months of inoculation. Similar behavior was found in the Prunus spp. $\times$ M. incognita pathosystem (Khallouk et al., 2011). Khallouk et al. (2011) observed that J2 were not able to dissolve the medial lamella between the root cells of Prunus spp., because Casparian strips reinforce the walls of the endoderm.

Due to the adaptability to different soil and climatic conditions, it is possible that E. stipitata possesses some mechanism of resistance similar to that observed in Prunus spp. (Khallouk et al., 2011). In this case, the energy expenditure is high for the $\mathrm{J} 2$ to locate and establish the feeding sites, leading to starvation of juveniles due to lack of nutrients. Thus, the development to adult stage is inhibited, reducing the chances of reproduction, which may help explain the low reproductive factor observed in E. stipitata.

The species $P$. acutangulum, $P$. guajava var. minor, $P$. guineense, and Psidium sp. allowed nematode multiplication and were classified as susceptible $(\mathrm{RF}>1)$, as well as with the 'Comprida Roxa' eggplant, which confirmed the viability of the inoculum (Table 1). The fungi Fusarium solani and Rhizoctonia solani were also identified in these species (araçá and eggplant) along with the galls, which are often associated with the decline of the guava tree (Gomes et al., 2013).

Along with xylem obstruction by gall-forming nematodes, the concomitant presence of soil fungi contributes to plant wilting in the hottest time of the day, even with adequate water. This shows that the synergistic effect of the pathosystem involving $M$. enterolobii and soil fungi, more frequently with the presence of $F$. solani, greatly aggravates plant damage, leading to the decline of guava trees (Gomes et al., 2013).

In general, complex diseases involving nematodes occur because the penetration of these pathogens provides entry points for microorganisms, including fungi, limiting growth, yield and, in extreme cases, resulting in the death of plants. The severity of root rot in the presence of $M$. enterolobii, as observed in susceptible araçá trees, may be caused by nematode infection inducing anatomic and physiological changes and predisposing the roots to increased fungal infection (Porter \& Powell, 1967). The interaction between nematodes and soil fungi causes significantly higher damage to cultivated plants (Fischer et al., 2010; Gomes et al., 2013; Al-Hazmi \& Al-Nadary, 2015). 
Table 1: Fresh mass of roots (RFM in grams), number of eggs, number of second-stage juveniles in the roots (J2), reproduction factor (RF), and reaction of araçá trees to Meloidogyne enterolobii

\begin{tabular}{lcllcc}
\hline Treatment & $\mathbf{R F M}^{(\mathbf{x})}$ & $\mathbf{E g g}^{(\mathbf{v} ; \mathbf{x})}$ & $\mathbf{J 2}^{(\mathbf{v} ; \mathbf{x})}$ & $\mathbf{R F}^{(\mathbf{x} ; \mathbf{w})}$ & Reaction $^{(\mathbf{y})}$ \\
\hline Psidium cattleyanum ‘yellow' $^{\text {‘ }}$ & $8.80 \mathrm{~d}$ & $0 \mathrm{a}$ & $0 \mathrm{a}$ & 0.00 & $\mathrm{R}$ \\
Psidium friedrichsthalianum $^{(\mathrm{z})}$ & $9.60 \mathrm{c}$ & $0 \mathrm{a}$ & $0 \mathrm{a}$ & 0.00 & $\mathrm{R}$ \\
Psidium friedrichsthalianum $^{(\mathrm{z})}$ & $11.05 \mathrm{~b}$ & $0 \mathrm{a}$ & $0 \mathrm{a}$ & 0.00 & $\mathrm{R}$ \\
Eugenia stipitata $^{\text {Psidium acutangulum }}$ & $10.95 \mathrm{~b}$ & $335 \mathrm{~b}$ & $175 \mathrm{~b}$ & 0.17 & $\mathrm{R}$ \\
Psidium guajava var. minor & $10.90 \mathrm{~b}$ & $83,630 \mathrm{c}$ & $20,300 \mathrm{c}$ & 34.64 & $\mathrm{~S}$ \\
Psidium guineense & $17.50 \mathrm{a}$ & $126,120 \mathrm{~cd}$ & $25,480 \mathrm{c}$ & 50.53 & $\mathrm{~S}$ \\
Psidium sp. & $10.05 \mathrm{c}$ & $203,285 \mathrm{~cd}$ & $33,775 \mathrm{~d}$ & 79.02 & $\mathrm{~S}$ \\
Solanum melongena (control) & $16.95 \mathrm{a}$ & $298,895 \mathrm{~d}$ & $44,875 \mathrm{~d}$ & 114.59 & $\mathrm{~S}$ \\
\hline
\end{tabular}

\begin{tabular}{lllc}
\hline Test F & $26.94^{* *}$ & $62.54^{* *}$ & $75.19^{* *}$ \\
\hline $\mathrm{CV}(\%)$ & 15.28 & 10.07 & 2.92
\end{tabular}

(v) Original data; for analysis, the values were transformed into $\log (x+5)$. Means followed by different letters in the column are significantly different by the Tukey's test $(\mathrm{p}<0.01)$. CV: coefficient of variation; **: significant at $1 \%$.

(x) Mean values of ten repetitions $(n=10)$.

(w) $\mathrm{RF}=\mathrm{Pf} / \mathrm{Pi}$, where: RF: reproduction factor; Pf: final population; Pi: initial population.

(y) Reaction of inoculated plants. FR<1: resistant (R); FR>1: susceptible (S).

(z) Genotypes of P. friedrichsthalianum.

The resistant araçá trees showed good formation and distribution of roots, mainly of radicels, and absence of galls, except for E. stipitata, which had some galls. The araçá trees $P$. guajava var. minor and Psidium sp., susceptible to $M$. enterolobii, even with the highest root mass, showed the root system basically with supporting roots, few radicels, many galls and necrosis (Table 1). This relationship between the increase in root mass and the increase in the population of gall nematodes has been attributed to the combined effect of the growth of new roots in the nematode-infected sites and the high number of galls (Maleita et al., 2012; Pereira et al., 2016).

Secondary symptoms were observed in the canopy of the susceptible araçá trees (tanning, yellowing, and leaf fall), with greater intensity in $P$. guajava var. minor and Psidium sp. Secondary symptoms were caused by damage to the root system, mainly due to scarcity of radicels, which reduced the volume of soil explored. Because of the reduction in the volume of the root system, there was less absorption and transport of water and soil nutrients, which affected the development and growth of plants. Due to this chain of events, visual nutrient deficiency symptoms were observed in the leaves of araçá species susceptible to $M$. enterolobii, mainly for nitrogen, phosphorus, potassium and magnesium, which are similar to those described in guava trees (Almeida et al., 2011).

\section{CONCLUSIONS}

M. enterolobii did not multiply on P. cattleyanum 'yellow' and P. friedrichsthalianum.

E. stipitata allows a little multiplication of $M$. enterolobii.
The araçá species $P$. cattleyanum 'yellow', $P$. friedrichsthalianum, and E. stipitata are resistant to $M$. enterolobii and can be tested as potential guava rootstocks.

\section{REFERENCES}

Al-Hazmi AS \& Al-Nadary SN (2015) Interaction between Meloidogyne incognita and Rhizoctonia solani on green beans. Saudi Journal of Biological Sciences, 22:570-574.

Almeida EJ, Santos JM \& Martins ABG (2009) Resistência de goiabeiras e araçazeiros a Meloidogyne mayaguensis. Pesquisa Agropecuária Brasileira, 44:421-423.

Almeida EJ, Santos JM \& Martins ABG (2011) Influência do parasitismo pelo nematoide de galhas nos níveis de nutrientes em folhas e na fenologia de goiabeira 'Paluma'. Bragantia, 70:876-881.

Biazatti MA, Souza RM, Marinho CS, Guilherme DO, Campos GS, Gomes VM \& Bremenkamp CA (2016) Resistência de genótipos de araçazeiros a Meloidogyne enterolobii. Ciência Rural, 46:418-420.

Cabasan MTN, Kumar A, Bellafiore S \& De Waele D (2014) Histopathology of the rice root-knot nematode, Meloidogyne graminicola, on Oryza sativa and O. glaberrima. Nematology, 16:73-81.

Carneiro RMDG, Moreira WA, Almeida MRA \& Gomes ACMM (2001) Primeiro registro de Meloidogyne mayaguensis em goiabeira no Brasil. Nematologia Brasileira, 25:223-228.

Cunha TPL, Mingotte FLC, Chiamolera FM, Carmeis Filho ACA, Soares PLM, Lemos LB \& Vendramini AR (2015) Ocorrência de nematoides e produtividade de feijoeiro e milho em função de sistemas de cultivo sob plantio direto. Nematropica, 45:34-42.

Das S, DeMason DA, Ehlers JD, Close TJ \& Roberts PA (2008) Histological characterization of root-knot nematode resistance in cowpea and its relation to reactive oxygen species modulation. Journal of Experimental Botany, 59:1305-1313. 
Eisenback JD \& Hirschimann H (1981) Identification of Meloidogyne species on the basic of head shape and stylet morphology of the male. Journal of Nematology, 13:513-521.

Esbenshade PR \& Triantaphyllou AC (1990) Isozyme phenotypes for the identification of Meloidogyne species. Journal of Nematology, 22:10-15.

Fischer IH, Bueno CJ, Garcia MJM \& Almeida AM (2010) Reação de maracujazeiro-amarelo ao complexo fusariose-nematoide de galha. Acta Scientiarum Agronomy, 32:223-227.

Franco CF \& Prado RM (2006) Uso de soluções nutritivas no desenvolvimento e no estado nutricional de mudas de goiabeira: macronutrientes. Acta Scientiarum. Agronomy, 28:199-205.

Freitas VM, Correa VR, Motta FC, Sousa MG, Gomes ACMM, Carneiro MDG, Silva DB, Mattos JK, Nicole M \& Carneiro RMDG (2014) Resistant accessions of wild Psidium spp. to Meloidogyne enterolobii and histological characterization of resistance. Plant Pathology, 63:738-746.

Gomes VM, Souza RM, Corrêa FM \& Dolinski C (2010) Management of Meloidogyne mayaguensis in commercial guava orchards with chemical fertilization and organic amendments. Nematologia Brasileira, 34:23-30.

Gomes VM, Souza RM, Silveira SF \& Almeida AM (2013) Guava decline: effect of root exudates from Meloidogyne enterolobiiparasitized plants on Fusarium solani in vitro and on growth and development of guava seedlings under controlled conditions. European Journal of Plant Pathology, 137:393-401.

Hussey RS \& Barker KR (1973) Comparison of methods of collecting inocula of Meloidogyne spp., including a new technique. Plant Disease Reporter, 57:1025-1028.

Khallouk S, Voisin R, Van Ghelder C, Engler G, Amiri S \& Esmenjaud D (2011) Histological mechanisms of the resistance conferred by the Ma gene against Meloidogyne incognita in Prunus spp. Phytopathology, 101:945-951.
Maleita CMN, Curtis RHC, Powers SJ \& Abrantes IMO (2012) Inoculum levels of Meloidogyne hispanica and M. javanica affect nematode reproduction, and growth of tomato genotypes. Phytopathologia Mediterranea, 51:566-576.

Moura RM \& Moura AM (1989) Meloidoginose da goiabeira: doença de alta severidade no Estado de Pernambuco, Brasil. Nematologia Brasileira, 13:13-19.

Oostenbrink R (1966) Major characteristics of the relation between nematodes and plants. Mededeelingen der LandbouwHoogeschool, 66:01-46.

Pereira FOM, Souza RM, Souza PM, Dolinski C \& Santos GK (2009) Estimativa do impacto econômico e social direto de Meloidogyne mayaguensis na cultura da goiaba no Brasil. Nematologia Brasileira, 33:176-181.

Pereira KC, Soares PLM, Santos JM, Batista ESP \& Maldonado Junior W (2016) Desenvolvimento de cultivares de goiabeira inoculadas com Meloidogyne enterolobii. Nematropica, 46:5459.

Porter DM \& Powell NT (1967) Influence of certain Meloidogyne species on Fusarium wilt development in flue-cured tobacco. Phytopathology, 57:282-285.

Rosa JMO, Westerich JN \& Wilcken SRS (2015) Reprodução de Meloidogyne enterolobii em olerícolas e plantas utilizadas na adubação verde. Revista Ciência Agronômica, 46:826-835.

Silva MCL \& Santos CDG (2017) Distribution of Meloidogyne enterolobii in guava orchards in the state of Ceará, Brazil. Revista Caatinga, 30:335-342.

Silva MCL, Santos CDG \& Silva GS (2016) Espécies de Meloidogyne associadas a vegetais em microrregiões do estado do Ceará. Revista Ciência Agronômica, 47:710-719.

Taylor DP \& Netscher C (1974) An improved technique for preparing perineal patterns of Meloidogyne spp. Nematologica, 20:268-269. 